This is a postprint of the paper published at Insect Systematics \&

Evolution http://booksandjournals.brillonline.com/content/journals/10.1163/1876312x$\mathbf{4 5 0 3 2 1 2 2}$ and deposited here in accordance with journals self-archiving policies

\title{
Orthoclads from Eocene Amber from Sakhalin (Diptera: Chironomidae, Orthocladiinae)
}

\section{Viktor Baranov $^{1,3^{*}}$, Trond Andersen ${ }^{2}$ and Evgeny Perkovsky ${ }^{1}$}

${ }^{1}$ I. I. Schmalhausen Institute of Zoology, National Academy of Sciences of Ukraine, B. Khmelnytskogo 15, 01601 Kiev, Ukraine

${ }^{2}$ Department of Natural History, University Museum of Bergen, University of Bergen, P.O. Box 7800, N-5020 Bergen, Norway

${ }^{3}$ Leibniz Institute for Freshwater Ecology and Inland Fisheries, Müggelseedamm 310, 12587 , Berlin, Germany (present address)

*Corresponding author, e-mail: baranowiktor@gmail.com

\begin{abstract}
Four Middle Eocene orthoclad species, Heterotrissocladius naibuchi sp. n., Paraphaenocladius nadezhdae sp. n., Pseudosmittia kodrulae sp. n., and Smittia sukachevae sp. n. are described and figured. Based on the combination of the diptera fauna composition and paleobotanical data, suggestions on the climate and habitats of the Sakhalin amber forest are given.
\end{abstract}

\section{Keywords}

Chironomidae; Orthocladiinae; new species; Sakhalin; amber; Eocene; climate

\section{Introduction}


During an expedition to Sakhalin in 1972 by the Paleontological Institute, Academy of Science of the USSR, numerous amber insects were collected (Zherikhin 1978). The amber was found on the beaches of the Okhotsk Sea near the Starodubskoye village in the Dolinsky district (South Sakhalin), near to the mouth of the Naiba River. In situ fossil resin of the same composition was also found nearby at the Naiba River (Dolinsky district), embedded in coal of the Naibuchi Formation (Kodrul 1999). The age of the amber was uncertain for a long time. In the 1970s, Sakhalinian amber was dated from the Paleocene (Danian) to the Eocene (Zherikhin 1978). However, Kodrul (1999) decisively dated the Naibuchi Formation to Middle Eocene.

Sakhalinian amber belongs to the rumanite-type amber. Common for such fossil resins is a high degree of polymerization of the resin itself and deformation caused by thermal metamorphosis during the diagenesis. Insect inclusions in rumanite-type (particularly Sakhalinian) amber are therefore often deformed and have their internal cavity filled with resin (Rasnitsyn \& Quicke 2002). Unfortunately, this reduces contrast between the inclusion and the matrix and so renders them inappropriate to study using techniques such as computed tomography.

In the southern part of South Sakhalin, the Naibuchi flora occupied vast stretches of alluvial lowlands along the seashores, with a dense net of rivers and large areas of intensive swamping, with the small lakes and swamps as dominating water body type, with active formation of the pit-bogs. Main coal-forming trees in the Dolinsky district was wood, shrub and grass species with Alnus Miller, 1754, Betula Linnaeus, 1753, Myrica Linnaeus, 1753, Salix Linnaeus, 1753, Taxodium (Linnaeus) Richard, 1810, Ericaceae, and Nymphaeaceae among the most abundant (Kodrul 1999). The Naibuchi flora differs from the Early Paleogene boreal floras by having a higher percentage of termophilous taxa and reflects a continuous change in climate conditions from humid, warm temperate climate in early stages to an almost subtropical climate in the last stages (Kodrul 1999: 78). Mosses found in Sakhalinian amber confirm swampy environments in Sakhalinian amber forest (Ignatov \& Perkovsky 2013).

About 840 inclusions of insects and arachnids were found in Sakhalinian amber, the most abundant of which were aphids and chironomids (Zherikhin 1978). However, most inclusions have so far not been studied in detail.

\section{Material and Methods}


The fossils were studied using a Nikon Optiphot 2 microscope. The drawings were made with the aid of a drawing tube, inked and processed in Adobe Photoshop CS5. The photos were taken with the aid of a Leica DM 400 B LED microscope using a Leica DFC 450C compact camera. The general terminology follows Sæther (1980). Measurements are given as ranges if more than a single specimen was measured.

All material studied is housed in the A.A. Borissiak Paleontological Institute, RAS, Moscow.

\section{The species}

\section{Genus Heterotrissocladius Spärck, 1923}

Type species: Metriocnemus cubitalis Kieffer, 1911.

Heterotrissocladius naibuchi sp. n. (Figs 1-3)

Type material. Holotype male. Russia: Sakhalin Oblast, Dolinsky District, Starodubskoye. Sakhalinian amber; specimen no PIN 3387/150.

The holotype (Fig. 1) is not well preserved: the thorax is almost completely distorted, the right wing is lost, left wing is lacking squama and partly covered with dark particles of angiosperm pollen, and the legs are mostly deformed. The hypopygium is in dorsal position.

Etymology. Named after the Naibuchi coal formation, in which the amber was found; Naibuchi is the Ainu name for Dolinsk.

Diagnostic characters. This species can be distinguished from the only known fossil species, H. paleolacustris Seredszus et Wichard, 2007 by having a double inferior volsella. It shows similarities to the extant $H$. maeaeri Brundin, 1949 which has an inferior volsella with two triangular to rounded lobes, but can be separated on the smaller size and the lower antennal ratio.

Description. Male $(\mathrm{n}=1)$. Total length $1.35 \mathrm{~mm}$. Wing length $1.08 \mathrm{~mm}$. Total length / wing length 1.25. Wing length / length of profemur 2.00. 
Head. Antenna with 13 flagellomeres, AR $=0.87$, length of terminal flagellomere 328 $\mu \mathrm{m}$. Outer verticals apparently 9 , inner verticals apparently 3 , postorbitals not visible. Clypeus apparently normal, with about 8 setae. Lengths (in $\mu \mathrm{m}$ ) of palpomere 2-5: 24, 40, 32, 44.

Thorax. Apparently with 6 antepronotals.

Wing (Fig. 2). Wing membrane densely covered with setae. Costa not extended, $\mathrm{R}_{4+5}$ ends slightly distal to end of $\mathrm{M}_{3+4}$.

Legs. Spur of fore tibia $38 \mu \mathrm{m}$ long, spurs of mid tibia 28 and $20 \mu \mathrm{m}$ long, of hind tibia 44 and $24 \mu \mathrm{m}$ long. Comb apparently with 10 setae, longest $40 \mu \mathrm{m}$ long, shortest $24 \mu \mathrm{m}$ long. Leg measurements as in Table 1.

Hypopygium (Fig. 3). Anal point triangular with rounded apex, $24 \mu \mathrm{m}$ long, with weak marginal setae. Inferior volsella well developed, consisting of two lobes; distal lobe broadly triangular, $48 \mu \mathrm{m}$ long (measured along gonocoxite), $36 \mu \mathrm{m}$ wide; smaller, proximal lobe triangular, $18 \mu \mathrm{m}$ long, $20 \mu \mathrm{m}$ wide. Gonocoxite $136 \mu \mathrm{m}$ long. Gonostylus spoon-shaped, 64 $\mu \mathrm{m}$ long; megaseta $12 \mu \mathrm{m}$ long. $\mathrm{HR}=2.13 . \mathrm{HV}=2.11$.

Remarks. We tentatively place the new species in Heterotrissocladius Spärck mainly based on the setose wing membrane, lack of costal extension, $\mathrm{R}_{4+5}$ ending distal to end of $\mathrm{M}_{3+4}$, and the general shape of the hypopygium. It also has a weak notch in the wing membrane where costa is joining $\mathrm{R}_{4+5}$, a character used by Cranston et al. (1989) to separate Heterotrissocladius from the similar genera Paratrissocladius Zavrel, 1937, Parametriocnemus Goetghebuer, 1932 and Paraphaenocladius Thienemann, 1924. However, with a wing length of only $1.08 \mathrm{~mm}$ the new species is distinctly smaller than extant Heterotrissocladius species with a wing length 1.9-3.3 mm (Cranston et al. 1989: 202) and also from the only known fossil species, $H$. paleolacustris, with a wing length of $1.9 \mathrm{~mm}$ (Seredszus \& Wichard 2007: 80). It also has a lower antennal ratio ( $\mathrm{AR}=0.87$ ) compared to modern Heterotrissocladius (AR = 1.0-2.1 (Cranston et al. 1989: 202)), but nearly similar to H. paleolacustris $(\mathrm{AR}=0.9$ (Seredszus \& Wichard 2007: 80)).

The new species is easily separated from the Late Eocene $H$. paleolacustris, which has an inferior volsella with a single lobe. It shows however, similarities to the extant $H$. maeaeri in having an inferior volsella with two lobes and might fit into the maeaeri-group sensu Sæther (1975). Also, the species shows similarities in the gonostylus and anal point shape with the Heterotrissocladius reductus Kong et Wang, 2011 from southern, oriental China (Kong \& Wang 2011). 
In addition to $H$. paleolacustris from Baltic amber, the genus Heterotrissocladius has been recorded from Middle Eocene Rovno amber (Zelentsov et al. 2012). Today the genus is distributed with 9 species in the Nearctic Region, 12 species in the Palaearctic Region and 6 species in the Oriental Region (Ashe \& O'Connor 2012).

\section{Genus Paraphaenocladius Thienemann, 1924}

Type species: Metriocnemus ampullaceus Kieffer, 1923.

Paraphaenocladius nadezhdae sp. n. (Figs 4-8)

Type material. Holotype male. Russia: Sakhalin Oblast, Dolinsky District, Starodubskoye. Sakhalinian amber; specimen no PIN N 3387/149. Paratype; same as holotype except PIN N $3387 / 148$.

The holotype (Fig. 7) is comparatively well preserved; in lateral position. The paratype (Fig. 8) is less well preserved; in lateral position.

Etymology. Named in remembrance of Dr. Nadezhda Kalugina, for her work on amber midges.

Diagnostic characters. The new species seems to be well separated from both extinct and extant Paraphaenocladius species. It can be separated from $P$. pusillus Seredszus et Wichard, 2007 from Mid Eocene Baltic amber by having an AR close to 1.0 compared to 0.7 in $P$. pusillus, by having a comparatively long costal extension ending distal to the end of $\mathrm{M}_{3+4}$, while in P. pusillus, costa is only slightly extended and ending proximal to the end of $\mathrm{M}_{3+4}$, and by having no setae on squama, while $P$. pusillus has a few setae on squama. It shows similarities to the extant $P$. pusillus Sæther et Wang, 1995 by having a bare squama, but can be separated on the higher antennal ratio and the much longer costal extension. [Note that the name $P$. pusillus Seredszus et Wichard, 2007 is preoccupied by $P$. pusillus Sæther et Wang, 1995. Paraphaenocladius pusillus Seredszus et Wichard should thus be given a replacement name].

Description. Male $(\mathrm{n}=1-2)$. Total length $1.53-1.89 \mathrm{~mm}$. Wing length $1.10-1.18 \mathrm{~mm}$. Total length / wing length 1.52-1.60. 
Head. Antenna with 13 flagellomeres, AR =0.97-0.99, length of terminal flagellomere 204-256 $\mu \mathrm{m}$. Lengths (in $\mu \mathrm{m}$ ) of palpomere 2-5: 40, 108, 96, 140.

Thorax (Fig. 4). Apparently with 3 antepronotals, about 10 acrostichals and 12 dorsocentrals.

Wing (Fig. 5). VR = 1.08-1.09. Costal extension 104-112 $\mu \mathrm{m}$ long. Wing membrane with setae in apical one-third. $\mathrm{R}, \mathrm{R}_{2+3}$, and $\mathrm{R}_{4+5}$ with setae; squama bare. $\mathrm{R}_{4+5}$ ends proximal to end of $\mathrm{M}_{3+4} \cdot \mathrm{Cu}_{1}$ sinuous.

Legs. Leg measurements as in Table 1.

Hypopygium (Fig. 6). Anal point triangular, 44-48 $\mu \mathrm{m}$ long, with $10 \mu \mathrm{m}$ long parallelsided, bare apex; with about 10 marginal setae. Gonocoxite 100-120 $\mu \mathrm{m}$ long. Gonostylus club-shaped, 60-68 $\mu \mathrm{m}$ long; megaseta $10 \mu \mathrm{m}$ long. $\mathrm{HR}=1.47-2.00$. HV $=2.55-2.78$.

Remarks. We tentatively place the new species in Paraphaenocladius Thienemann mainly based on the hairy wing membrane, long acrostichals beginning near antepronotum, and the curved $\mathrm{Cu}_{1}$. The new species has a long costal extension and $\mathrm{R}_{4+5}$ ends proximal to the end of $\mathrm{M}_{3+4}$. These characters separate Paraphaenocladius from Heterotrissocladius Spärk which has no costal extension and $\mathrm{R}_{4+5}$ ending distal to the end of $\mathrm{M}_{3+4}$. To separate male imagines of Paraphaenocladius from male imagines of Parametriocnemus Goetghebuer can be more difficult (see Sæther \& Wang 1995). In Paraphaenocladius $\mathrm{R}_{4+5}$ always ends proximal to the end of $\mathrm{M}_{3+4}$, while in Parametriocnemus $\mathrm{R}_{4+5}$ ends opposite to or more often distal to the end of $\mathrm{M}_{3+4}$. Both genera have a costal extension, and in male Paraphaenocladius the costal extension also ends proximal to the end of $\mathrm{M}_{3+4}$, while in the females it might end opposite to or slightly distal to the end of $\mathrm{M}_{3+4}$. The new species has a comparatively long costal extension which ends distinctly distal to the end of $\mathrm{M}_{3+4}$, thus being somewhat intermediate between the two genera regarding these characters. However, another distinction might be that the new species lacks setae on squama. Parametriocnemus has few to several setae on squama. Most Paraphaenocladius also have few to several setae on squama, but in P. pusillus Sæther et Wang, 1995 squama is bare.

Paraphaenocladius pusillus Seredszus et Wichard from Baltic amber is the only fossil Paraphaenocladius species described so far. The genus comprise 25 modern species with 1 species recorded from the Neotropical Region, 9 from the Nearctic Region, 18 from the Palaearctic Region, 3 from the Afrotropical Region, 3 from the Oriental Region and 1 species from Oceania (Ashe \& O'Connor 2012). 


\section{Genus Pseudosmittia Goetghebuer, 1932}

Type species: Spaniotoma angusta Edwards, 1929.

Pseudosmittia kodrulae sp. n. (Figs 9-12)

Material. Male. Russia: Sakhalin Oblast, Dolinsky District, Starodubskoye. Sakhalinian amber; specimen no PIN 3387/153.

The holotype (Fig. 9) is quite well preserved: the thorax is almost complete and antennae and legs are comparatively well preserved, the wings are present, but the wing veins are very difficult to observe, the hypopygium is in lateral position.

Etymology. Named after paleobotanist Tatiana M. Kodrul, who determined the age of Naibuchi Formation.

Diagnostic characters. The species can be separated from all other described Pseudosmittia species on its small size with a wing length of about $0.6 \mathrm{~mm}$, the triangular anal point in the middle of tergite IX, not extending to the posterior margin of the tergite, a virga consisting of two strong spines, a very low antennal ratio, and the comparatively long costal extension.

Description. Male $(\mathrm{n}=1)$. Total length $0.80 \mathrm{~mm}$. Wing length $0.63 \mathrm{~mm}$. Total length / wing length 1.27 .

Head. Antenna (Fig. 11) with 13 flagellomeres, $A R=0.20$, length of terminal flagellomere $59 \mu \mathrm{m}$.

Wing (Fig. 10). Costal extension $78 \mu \mathrm{m}$ long.

Thorax. Dorsocentrals about 10. Scutellum apparently with 2 setae.

Legs. Fore leg lost; length and proportions of mid- and hind legs as in Table 3.

Hypopygium (Fig. 12). Anal point triangular, $27 \mu \mathrm{m}$ long, sitting high on tergite IX; posterior margin of tergite IX rounded with marginal setae. Inferior volsella apparently low, rounded, with marginal setae. Virga of two strong spines, $29 \mu \mathrm{m}$ long. Gonocoxite about 68 $\mu \mathrm{m}$ long.

Remarks. We tentatively place the specimen in Pseudosmittia Edwards, mainly based on the triangular anal point sitting in the middle of tergite IX, and not extending to the posterior 
margin of the tergite. Pseudosmittia generally has two short, mostly biserial acrostichals on mid scutum without additional tubercle, hump or microtrichial tuft. No acrostichals can be observed in the present specimen, but these acrostichals can be tiny and difficult to observe even in modern specimens. Pseudosmittia generally has a single, plate-like median virga, but a virga consisting of two strong, spines is present in several species like $P$. carioca Andersen, Sæther et Mendes, 2010. Costa is generally not to moderately extended in Pseudosmittia, but some species like P. amorini Andersen, Sæther et Mendes, 2010 has an equally long costal extension. The antennal ratio is very low $(A R=0.20)$ in the new species, but it is very small and a comparatively low antennal ratio is found in other small Pseudosmittia species like $P$. holsata Thienemann et Strenzke, 1940.

No Pseudosmittia has been described from amber. Extant Pseudosmittia was recently revised by Ferrington \& Sæther (2011); the Neotropical species were reviewed by Andersen et al. (2010). Ferrington \& Sæther (2011) split Pseudosmittia in 15 species groups; $P$. kodrulae sp. n. might belong to their brevifurcata-group, based on the shape of the virga and the inferior volsella.

The genus comprise 96 extant species with 26 species recorded from the Neotropical Region, 18 from the Nearctic Region, 25 from the Palaearctic Region, 17 from the Afrotropical Region, 12 from the Oriental Region, 13 from Australasia and 15 species from Oceania (Ashe \& O'Connor 2012; Mauad et al. 2013).

\section{Genus Smittia Holmgren, 1869}

Type species: Chironomus brevipennis Bohemann, 1865.

Smittia sukachevae sp. n. (Figs 13-16)

Material. Male. Russia: Sakhalin Oblast, Dolinsky District, Starodubskoye. Sakhalinian amber; specimen no PIN N 3387/152.

The holotype (Fig. 13) is comparatively well preserved, in dorso-ventral position. Wing veins, except costa and radial sector, are barely discernable.

Etymology. Named after Dr. Irina D. Sukacheva in appreciation of her great input to the research of fossil resins and their inclusions in eastern Russia. 
Diagnostic characters. The species can be separated from all other described Smittia species on its small size with a wing length of about $0.8 \mathrm{~mm}$, the triangular anal point with marginal setae and the narrow, curved gonostylus.

Description. Male $(\mathrm{n}=1)$. Total length $1.34 \mathrm{~mm}$. Wing length $0.80 \mathrm{~mm}$. Total length / wing length 1.68. Wing length / length of profemur 2.13.

Head. Antenna (Fig. 15) with 13 flagellomeres, $A R=0.64$, length of terminal flagellomere $192 \mu \mathrm{m}$, subapical seta $28 \mu \mathrm{m}$ long. Lengths (in $\mu \mathrm{m}$ ) of palpomere 3-5: 52, 68, 92.

Thorax. Dorsocentrals 12.

Wing (Fig. 14). Costal extension $75 \mu \mathrm{m}$ long. Wing membrane bare. R with 4 setae; other veins and squama bare.

Legs. Longest spur of mid tibia $24 \mu \mathrm{m}$ long, of hind tibia $36 \mu \mathrm{m}$ long. Leg measurements as in Table 4.

Hypopygium (Fig. 16). Anal point triangular with rounded apex, $20 \mu \mathrm{m}$ long, $24 \mu \mathrm{m}$ wide at base, with strong marginal setae. Inferior volsella low. Gonocoxite $108 \mu \mathrm{m}$ long. Gonostylus curved, $56 \mu \mathrm{m}$ long; megaseta $12 \mu \mathrm{m}$ long. $\mathrm{HR}=1.92$. HV $=2.39$.

Remarks. We tentatively place the specimen in Smittia Holmgren based on the strong, subapical seta on the antenna, and by having bare wing membrane and squama. However, the hypopygium is not typical for Smittia and based on the hypopygium it might fit better into Sublettiella Sæther, 1983, which also possesses most of the above mentioned characters. Sublettiella is monotypic with S. clavata Sæther, 1983 from South Carolina, U.S.A and according to Sæther (1983) the costa is only slightly extended, the wing membrane has moderate punctuation and the squama is bearing a few setae. The present specimen has no seta on squama, a comparatively long costal extension and the wing membrane seems to have very fine punctuation.

The only named fossil Smittia, S. veta Boesel, 1937, is described from Upper Cretaceous Canadian amber (Evenhuis 1994). The wing seems to fit the diagnosis of Smittia, but other diagnostic characters as the subapical seta on the antenna, fringe on squama and the shape of the hypopygium are not or poorly described (Boesel 1937). Zelentsov et al. (2012) also record Smittia from Mid Eocene Rovno amber. The genus comprise 83 extant species with 14 species recorded from the Nearctic Region, 59 from the Palaearctic Region, 8 from 
the Afrotropical Region, 7 from the Oriental Region, 3 from Australasia and 1 species from Oceania (Ashe \& O'Connor 2012).

Orthocladiinae sp. A. (Fig. 17)

Material. Male. Russia: Sakhalin Oblast, Dolinsky District, Starodubskoye. Sakhalinian amber; specimen no PIN N 3387/154.

The specimen (Fig. 17) is in a poor state of the preservation. It has a ceratopogonid male (Diptera: Ceratopogonidae) as a syninclusion.

Remarks. The specimen has a strong, subapical setae on the terminal flagellomere of the antennae, bare eye and wing membrane, squama with at least 2 setae, no pulvilli, a rounded anal point with several strong setae, and a club-shaped gonostylus. Based on this combination of characters it does not readily fit into any described genus.

Orthocladiinae sp. B. (Fig. 18)

Material. Male. Russia: Sakhalin Oblast, Dolinsky District, Starodubskoye. Sakhalinian amber; specimen no PIN N 3387/155.

The specimen (Fig. 18) is rather badly damaged, lacking one wing. On the abdominal sternites behind the thorax, the specimen is bearing a large mite (Acari).

Remarks. Correct placement of this specimen is difficult. However, presence of setae on the wing membrane at least near the wing tip and the general shape of the hypopigium indicate that it might belong in Parametriocnemus or Paraphaenocladius.

Orthocladiinae sp. C. (Fig. 19)

Material. Male. Russia: Sakhalin Oblast, Dolinsky District, Starodubskoye. Sakhalinian amber; specimen no PIN N 3387/156. 
A strongly damaged specimen (Fig. 19), with thorax, base of the wings and legs poorly preserved. It has a ceratopogonid male (Diptera: Ceratopogonidae) and the remains of an unidentified Nematocera female as syninclusions.

Remarks. Correct placement is impossible, but some characters, like a long costal extension, low AR, a triangular anal point sitting high on the tergite and the shape of gonostylus might indicate a placement in Pseudosmittia (see Cranston et al. 1989; Ferrington \& Sæther 2011).

\section{Discussion}

About 840 inclusions of arthropods are known from the Sakhalinian amber. Among these, 350 chironomids have been found, all of them belonging to the subfamily Orthocladiinae (Zherikhin 1978). The inclusions are kept at the A. A. Borissiak Paleontological Institute of the Russian Academy of Science, Moscow. As the specimens generally are poorly preserved and many specimens are deformed, which is a common feature for inclusions in ambers of the rumanite-type, they have received little attention from paleodipterologists (Rasnitsyn \& Quicke 2002). Only one species of Chironomidae, the orthoclad Pseudorthocladius zherikhini Baranov et Perkovsky, 2013, has so far been described from this deposit (Baranov \& Perkovsky 2013). We have examined 81 inclusions and selected 8 males which are reasonably well preserved. Based on these inclusions we describe four new species, Heterotrissocladius naibuchi sp. n., Paraphaenocladius nadezhdae sp. n., Pseudosmittia kodrulae sp. n., and Smittia sukachevae sp. n., while we find the remaining specimens not well enough preserved to suggest any placement in genus.

A recent dated phylogenetic analysis of the Chironomidae shows at least a Lower Cretaceous, if not a Jurassic origin of the Orthocladiinae (Cranston et al. 2012). From Cretaceous Lebanese amber only one orthoclad species, Lebanorthocladius furcatus Veltz, Azar et Nel, 2007, has been described, while three species, Metriocnemus cretatus Boesel, 1937, Smittia veta Boesel, 1937 and "Spaniotoma" conservata Boesel, 1937 have been described from Cretaceous Canadian amber (Boesel 1937). In Cretaceous amber from the Taimyr only the subfamilies Aenninae and Diamesinae have been found (Veltz et al. 2007; Kalugina 1976, 1980). However, Orthocladiinae is the most common subfamily of Chironomidae in all Cenozoic ambers (Zelentsov et al. 2012). 
Kalugina $(1974,1980)$ demonstrated that the subfamily composition of Chironomidae in lentic habitats changed from predominately Podonominae in the Lower Jurassic to Orthocladiinae and Chironominae in the Cenozoic ecosystems. She suggested that this dramatic change in community structure, which also included a dramatic decrease in Plecoptera larvae and some aquatic beetles, could be the result of a massive mid-Cretaceous eutrophication of lentic habitats caused by mass occurrence of angiosperm trees, as falling leaves would become an important source of organic matter in freshwater ecosystems (Kalugina 1974). She argued that before the mass occurrence of the angiosperms most lentic water bodies were comparatively oligotrophic, which allowed Podonominae larvae and Plecoptera nymphs to thrive. After the mass eutrophication these taxa colonized streams and northern oligotrophic lakes, while many lentic water bodies obtained communities more similar to extant ones. In light of this, the low abundance of the Orthocladiinae in Cretaceous deposits and the "explosion" in Cenozoic deposits could be caused by a change in environmental conditions rather than a late origin of the orthoclads. This opinion is also supported by the changes in the diversity and abundance of the dragonflies in the Cretaceous (Fleck \& Nel 2003). They demonstrated that the widespread and abundant Odonata family Aeshnidae virtually vanished from the geological records somewhere in the Cenomanian age of Cretaceous. Some authors (Bechly 1998) suggested that birds emerging in cretaceous led to the extinction of the large, colorful dragonflies - like Aeshnidae or families from the Anisozygoptera suborder, however this opinion contrasts with the evidence of the long lasting co-existence of the early birds and Aeshnidae in the Lower Cretaceous (Fleck \& Nel 2003). Thus, Fleck \& Nel (2003) stated that a possible reason for the Aeshnidae extinction was the major changes in the ecosystems caused by the Angiosperms diversification.

Currently six genera of the Orthocladiinae are recorded from the Sakhalin amber, Antillocladius Saether, 1981; Heterotrissocladius Spärck; Paraphaenocladius Thienemann; Pseudorthocladius Goetghebeur, 1932; Pseudosmittia Edwards and Smittia Holmgren.

However, the generic placements must be regarded as tentative. Nevertheless, a distribution analysis could be helpful for further research. Although the above genera are widely distributed (Ashe \& O'Connor 2012), at least Paraphaenocladius and Heterotrissocladius could be treated as "Holarctic" sensu Dlussky \& Rasnitsyn (2009) and Perkovsky (2011), that is, of predominantly northern temperate distribution with later expansions to subtropical and tropical areas (see Saether \& Ekrem 2003). The majority of the Pseudorthocladius species (46) are recorded from the Holarctic region, seven species are from the Oriental region, and only two from the Afrotropical region (Ashe \& O’Connor 2012). Among the Oriental species 
three are known only from the subtropical Ryukyu Islands and Fujian and one more is from the Himalayas (Ashe \& O’Connor 2012). The genus Antillocladius includes 24 species from the Neotropical, Nearctic and Oriental zoogeographical regions (Mendes et al. 2011). Antillocladius is mostly a tropical or warm-temperate genus, sometimes going quite far to the north as shown by A. scalpellatus Wang et Sæther, 1993 recorded from the Primorskiy Kraj in Russia (Tiunova et al. 2003). Thus the presence of Antillocladius in the amber from Sakhalin does not contradict the assumption of a temperate climate and swampy landscape of Sakhalin in the Middle Eocene. Both Smittia and Pseudosmittia are extremely diverse and widespread genera (see Ashe \& O'Connor 2012), so it is difficult to use them in the paleoclimatological inference.

The specimens we have examined from the amber from Sakhalin are generally quite small with a wing length of about $1.0 \mathrm{~mm}$ or less and Heterotrissocladius naibuchi sp. n., Paraphaenocladius nadezhdae sp. n., Pseudosmittia kodrulae sp. n., Pseudorthocladius zherikhini, Antillocladius sp. and Smittia sukachevae sp. n. all have lower antennal ratio than most extant species of the genera. As shown by Sæther \& Andersen (1996) such combination of characters is typical for tropical and subtropical representatives of widespread genera. Further, H. naibuchi is lacking the anal lobe, which is unusual for this genus (Sæther 1975). This might suggest a warm climate in the region on the Late Eocene, which, however, does not fit the reconstruction by Kodrul (1999).

The climate of the Kama floral age which proceeded the Naibuchi age was moist temperate to warm temperate. The Kama flora consists of about $70 \%$ of species which are shared with other temperate and warm temperate floras of the boreal zone of the Early Paleogene. The Naibuchi flora (Middle Eocene) is strongly rooted in the Kama flora and the Early Paleogene boreal floras in general. In the southern part of South Sakhalin, the Naibuchi flora occupied vast stretches of alluvial lowlands along the seashores, with a dense net of rivers and vast areas with small lakes and swamps as dominating water body type, and with active formation of peat-bogs. Based on the palynological analysis of the coal seams of the Lopatinskij field (Dolinsky district) (Sinitsyn 1963), main coal producing plants in the Dolinsky district were Osmunda, Taxodium (up to 95\%), Alnus (up to 63\%), Betula, Salix, Myrica, Ericaceae, and Nymphaeaceae (Kodrul 1999). Taxa associated with leaf-litter are scarce in the Sakhalinian amber, which is also characteristic for swamps (Zherikhin 1978). The Lopatinskiy and Sinegorskiy coal fields in the Dolinsky district are in the area of spread of siltstones and mudstones of lacustrine facies, with multiple layers of coal. Paleogeographic condition confirms continued existence of swampy coastal plains (Kodrul, 1999). Among the 
five species of the fungus-gnats (Mycetophylidae) found in Sakhalin amber, only one belongs to a genus associated with terrestrial fungi, while the remaining are associated with moist dead wood and xylophagous fungi (Blagoderov 2007). However, the Naibuchi flora differs from the other Early Paleogene boreal ones in having a higher abundance of thermophile taxa and so reflects environmental changes from humid, warm temperate climate in early stages to an almost subtropical climate in the last stages (Kodrul 1999: 78).

\section{Acknowledgements}

We are indebted to Professor Alexandr Rasnitsyn, A. A. Borissiak Paleontological Institute of Russian Academy of Science, Moscow, for kindly loaning us the inclusions from Sakhalin, to Dr. Irina Sukacheva (Borisiak Paleontological Institute), for her indispensable help with amber studies. We are also grateful to Dr. Elena Lukashevich (Borissiak Paleontological Institute) and Dr. Tatiana Kodrul (Geological Institute of Russian Academy of Science, Moscow), for discussions on nematoceran paleontology and the age of the Sakhalin amber. Mrs. Antonia Guidotti, Royal Ontario Museum, kindly made photos of the Boesel's Chironomidae types, and Dr. Janet Waddington sent them to us. Viktor Baranov's work in the collection at the University Museum of Bergen was supported by the Ernst Mayr travel grant from Harvard Museum of Comparative Zoology.

\section{References}

Andersen, T., Sæther, O.A. \& Mendes, H.F. (2010) Neotropical Allocladius Kieffer, 1913, and Pseudosmittia Edwards, 1932 (Diptera: Chironomidae). Zootaxa 2472: 1-77.

Ashe, P. \& O'Connor, J.P. (2012) A World Catalogue of Chironomidae (Diptera). Part 2. Orthocladiinae (Section A \& Section B). Irish Biogeographical Society \& National Museum of Ireland, Dublin, xvi +968 pp.

Baranov, V. \& Perkovsky, E.E. (2013) New chironomids from Eocene Sakhalin amber (Diptera; Chironomidae; Orthocladiinae). Terrestrial Arthropod Reviews 6: 61-69.

Bechly, G. (1998) A revision of the fossil dragonfly genus Urogomphus, with description of a new species (Insecta: Odonata: Pananisoptera: Aeschnidiidae). Stuttgarter Beiträge zur Naturkunde (Serie B) 270: 1-47. 
Blagoderov, V. (2007) New species of fungus gnats (Diptera: Mycetophilidae) from the Palaeocene Sakhalin Amber, Russia. Alavesia 1: 27-36.

Boesel, M.W. (1937). Order Diptera, Family Chironomidæ. In: Carpenter, F.M., Folsom, J.W., Essig, E.O., Kinsey, A.C., Brues, C.T., Boesel, M.W. \& Ewing, H.E. (Eds.), Insects and Arachnids from Canadian amber. University of Toronto Studies, Geological Series 40: 44-55.

Cranston, P.S., Oliver, D.R. \& Sæther, O.A. (1989) The adult males of Orthocladiinae (Diptera: Chironomidae) of the Holarctic region - Keys and diagnoses. In: Wiederholm, T. (Ed.), Chironomidae of the Holarctic region. Keys and diagnoses. Part 3 - Adult males. Entomologica scandinavica, Supplement 34: 165-352.

Cranston, P.S., Hardy, N.B. \& Morse, G.E. (2012) A dated molecular phylogeny for the Chironomidae (Diptera). Systematic Entomology 37: 172-188.

Dlussky, G.M. \& Rasnitsyn, A.P. (2009) Ants (Insecta: Vespida: Formicidae) in the Upper Eocene amber of central and eastern Europe. Paleontological Journal 43: 1024-1042.

Evenhuis, N.L. (1994) Catalogue of the fossil flies of the world. Backhuys Publishers, Leiden, viii +600 pp.

Ferrington, L.C. jr. \& Sæther, O.A. (2011) A revision of the genera Pseudosmittia Edwards, 1932, Allocladius Kieffer, 1913, and Hydrosmittia gen. n. (Diptera: Chironomidae, Orthocladiinae). Zootaxa 2849: 1-314.

Fleck, G. \& Nel, A. (2003) Revision of the Mesozoic family Aeschnidiidae (Odonata : Anisoptera). Zoologica 153: 1-180.

Ignatov, S.I. \& Perkovsky, E.P. (2013) Mosses from sakhalinian amber (Russian Far East), Arctoa 22: 79-82.

Kalugina, N.S. (1974) Changes in the subfamily composition of the chironomids (Diptera, Chironomidae) as indicator of a possible eutrophication of waterbodies during the late Mesozoic era. [Izminenija podsemeistvennogo sostava chironomid (Diptera, Chironomidae) kak pokazatel vozmozhnogo evtrofirovania vodoemov v kocne Mesozoja]. Bulletin of MOIP, Biological division 79(6): 45-56 [in Russian]. Kalugina, N.S. (1976) Non-biting midges of the subfamily Diamesinae (Diptera, Chironomidae) from the Upper Cretaceous of the Taimyr. [Komari-Zvonci podsemeistva Diamesinae (Diptera, Chironomidae) iz verhnego Mela Taimyra]. Paleontological Journal 10(1): 78-83 [in Russian]. 
Kalugina, N.S. (1980) Cretaceous Aphroteniinae from North Siberia (Diptera, Chironomidae). Electrotenia brundini gen. nov., sp. nov. Acta Universitatis Carolinae Biologica 1978: 89-93.

Kodrul, T.M. (1999) Paleogene phytostratigraphy of the South Sakhalin. [Paleogenovaja paleostratigraphija Juzhnogo Sakhalins]. Transactions of GIN RAS 519: 1-150 [in Russian].

Kong, F. \& Wang, X. (2011) Heterotrissocladius Spärck from China (Diptera: Chironomidae). Zootaxa 2733: 63-68.

Mauad, M., Siri, A. \& Donato, M. (2013) New species of Pseudosmittia Edwards, 1932 and new records of Allocladius Kieffer, 1913 (Diptera: Chironomidae, Orthocladiinae) from South America. Zootaxa 3694: 445-460.

Mendes, F.H., Andersen, T. \& Hagenlund, L.K. (2011) New species and records of Antillocladius Sæther and Litocladius Mendes, Andersen et Sæther from Brazil and Costa Rica (Chironomidae: Orthocladiinae). Zootaxa 2915: 39-51.

Perkovsky, E.E. (2011). Syninclusions of the Eocene winter ant Prenolepis henschei (Hymenoptera: Formicidae) and Germaraphis aphids (Hemiptera: Eriosomatidae) in the Late Eocene Baltic and Rovno ambers: some implications. Russian Entomological Journal 20: 303-313.

Rasnitsyn, A.P. \& Quicke, D.L.J. (Eds.) (2002) History of Insects. Kluwer Academic Publishers, Dordrecht, 517 pp.

Sæther, O.A. (1975) Nearctic and Palaearctic Heterotrissocladius (Diptera: Chironomidae). Bulletin of the Fisheries Research Board of Canada 193: 1-67.

Sæther, O.A. (1980) Glossary of chironomid morphology terminology (Diptera: Chironomidae). Entomologica scandinavica, Supplement 14: 1-51.

Sæther, O.A. (1983) A review of Holarctic Gymnometriocnemus Goetghebuer, 1932, with the description of Raphidocladius subgen. n. and Sublettiella gen. n. (Diptera:

Chironomidae). Aquatic Insects 5: 209-226.

Sæther, O.A. \& Andersen, T. (1996) First Afrotropical records of Doithrix and Georthocladius, with notes on the Pseudorthocladius group (Diptera: Chironomidae). Tijdschrift voor Entomologie 139: 243-256.

Sæther, O.A. \& Ekrem, T. (2003) Biogeography of afrotropical Chironomidae (Diptera), with special reference the Gondwanaland. Cimbebasia 19: 123-139. 
Sæther, O.A. \& Wang, X. (1995) Revision of the genus Paraphaenocladius Thienemann, 1924 of the world (Diptera: Chironomidae, Orthocladiinae). Entomological Scandinavica, Supplement 48: 3-69.

Seredszus, F. \& Wichard, W. (2007) Fossil chironomids (Insecta, Diptera) in Baltic amber. Palaeontographica. Abteilung A: Paläozoologie - Stratigraphie 279: 49-91.

Sinitsyn, V.M. (Ed.) (1963) History of paleogenic coal accumulation at the territory of Island Sakhalin. [Istoriya paleogenovogo uglenakoplenia na teritorii Sakhalina]. Izdatelstvo Akademii Nauk SSSR, Moskow - Leningrad, 168 pp. [in Russian].

Tiunova, T.M., Teslenko, V.A., Arefina, T.I., Makarchenko, M.A. \& Zorina, O.V. (2003) Fauna of aquatic insects in Barabashevka river basin (Southern Primorye). Vladimir Ya. Levanidov's Biennial Memorial Meetings 2: 61-69.

Veltz, I., Azar, D. \& Nel, A. (2007) New chironomid flies in Early Cretaceous Lebanese amber (Diptera: Chironomidae). African Invertebrates 48: 169-191.

Zelentsov, N.I., Baranov, V.A., Perkovsky, E.E. \& Shobanov, N.A. (2012) First records of non-biting midges (Diptera: Chironomidae) from the Rovno amber. Russian Entomological Journal 21: 79-87.

Zherikhin, V.V. (1978) Development and changes of the Cretaceous and Cenozoic faunal assemblages (Tracheata and Chelicerata). Trudy Paleontologicheskogo Instituta Akademii Nauk SSSR 165: 1-198. 
Text to figures

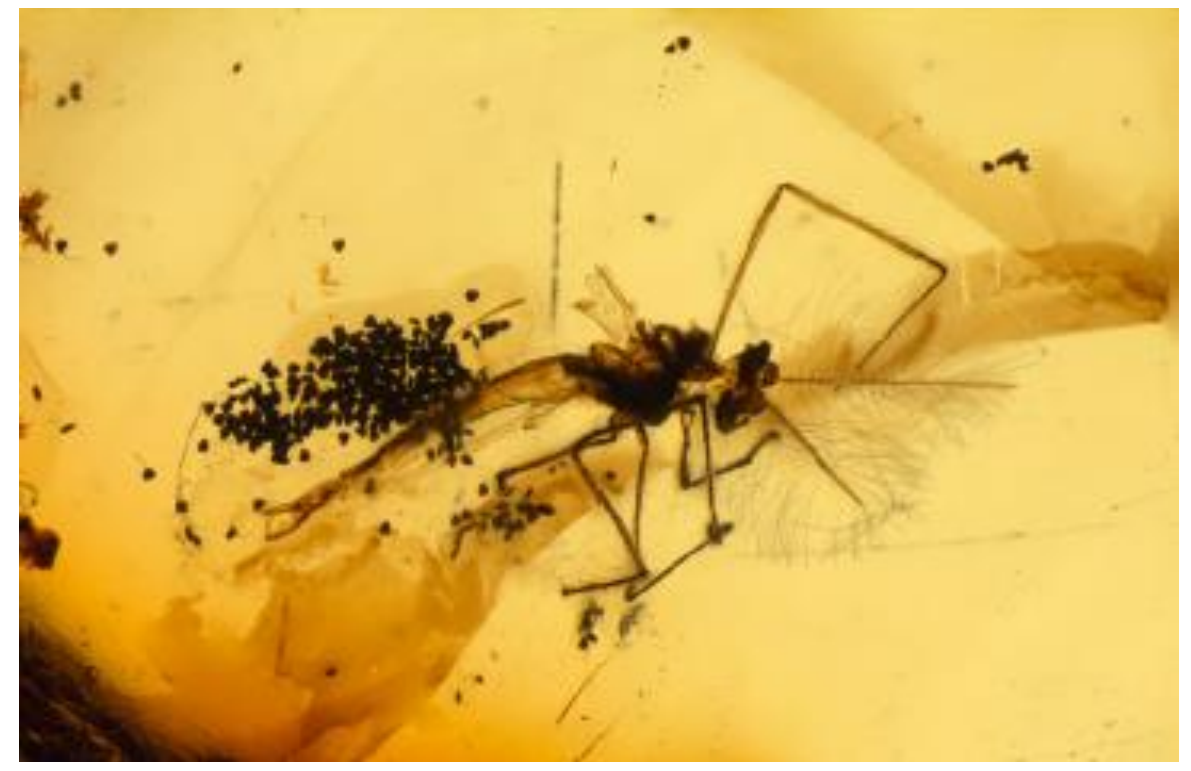

Fig. 1. Heterotrissocladius naibuchi sp. n., holotype male (PIN 3387/150). 

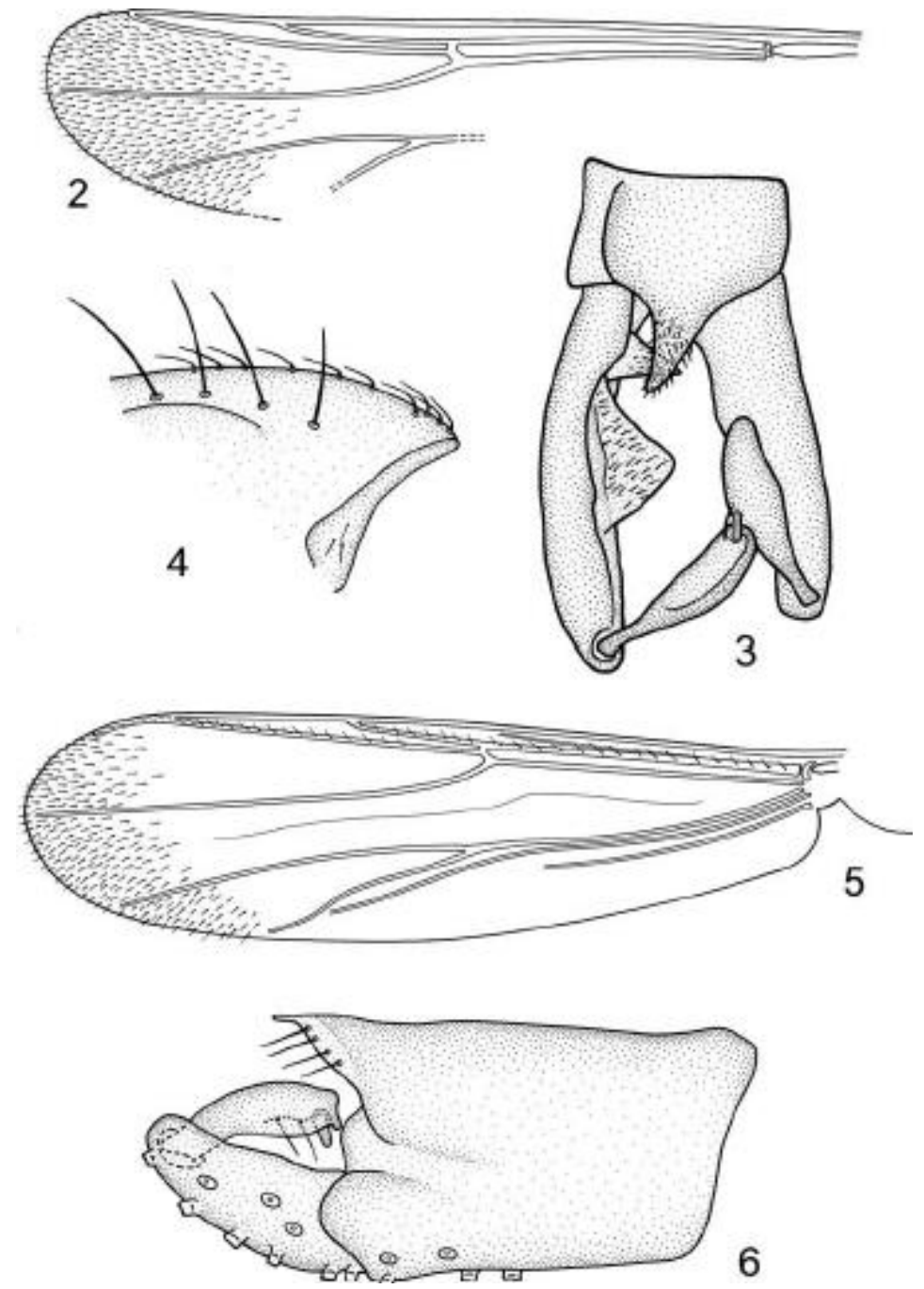

Figs 2-6. (2-3) Heterotrissocladius naibuchi sp. n., holotype male (PIN 3387/150), (2) wing, (3) hypopygium. (4) Paraphaenocladius nadezhdae sp. n., paratype male (PIN N 3387/148), anterior part of scutum. (5-6) Paraphaenocladius nadezhdae sp. n., holotype male (PIN N 3387/149), (5) wing, (6) hypopygium.

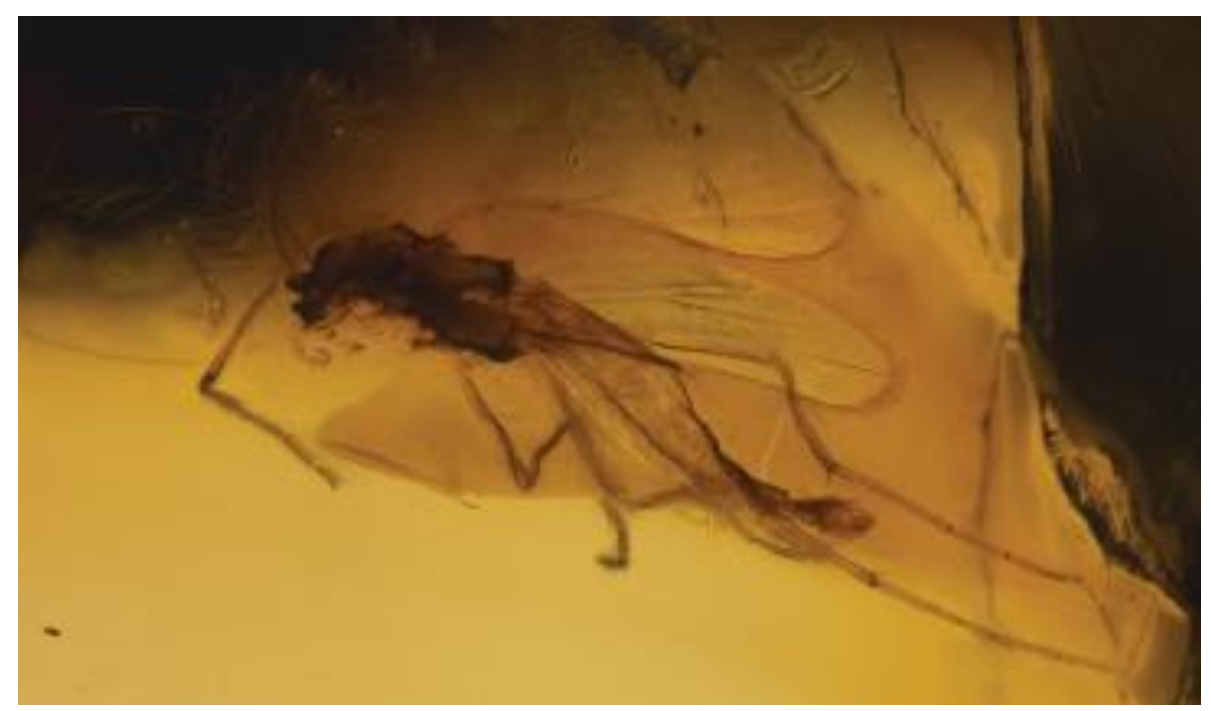

Fig. 7. Paraphaenocladius nadezhdae sp. n., holotype male (PIN N 3387/149). 


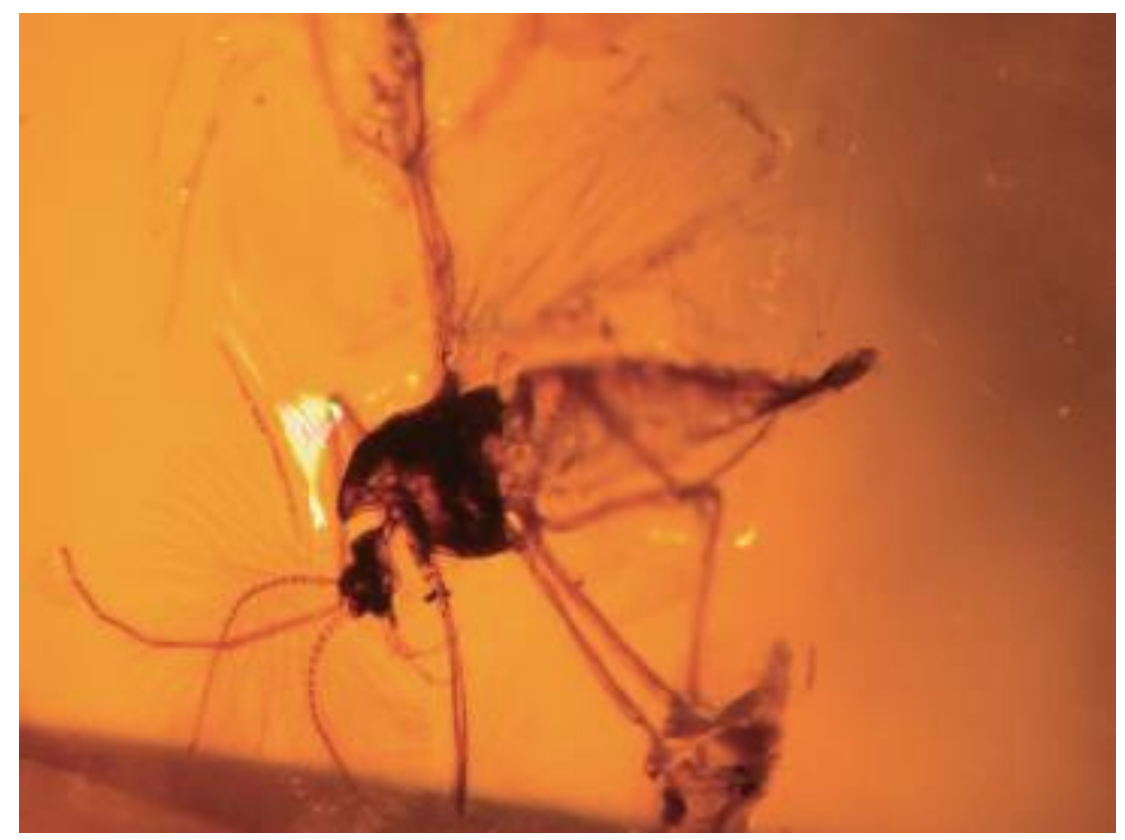

Fig. 8. Paraphaenocladius nadezhdae sp. n., paratype male (PIN N 3387/148).

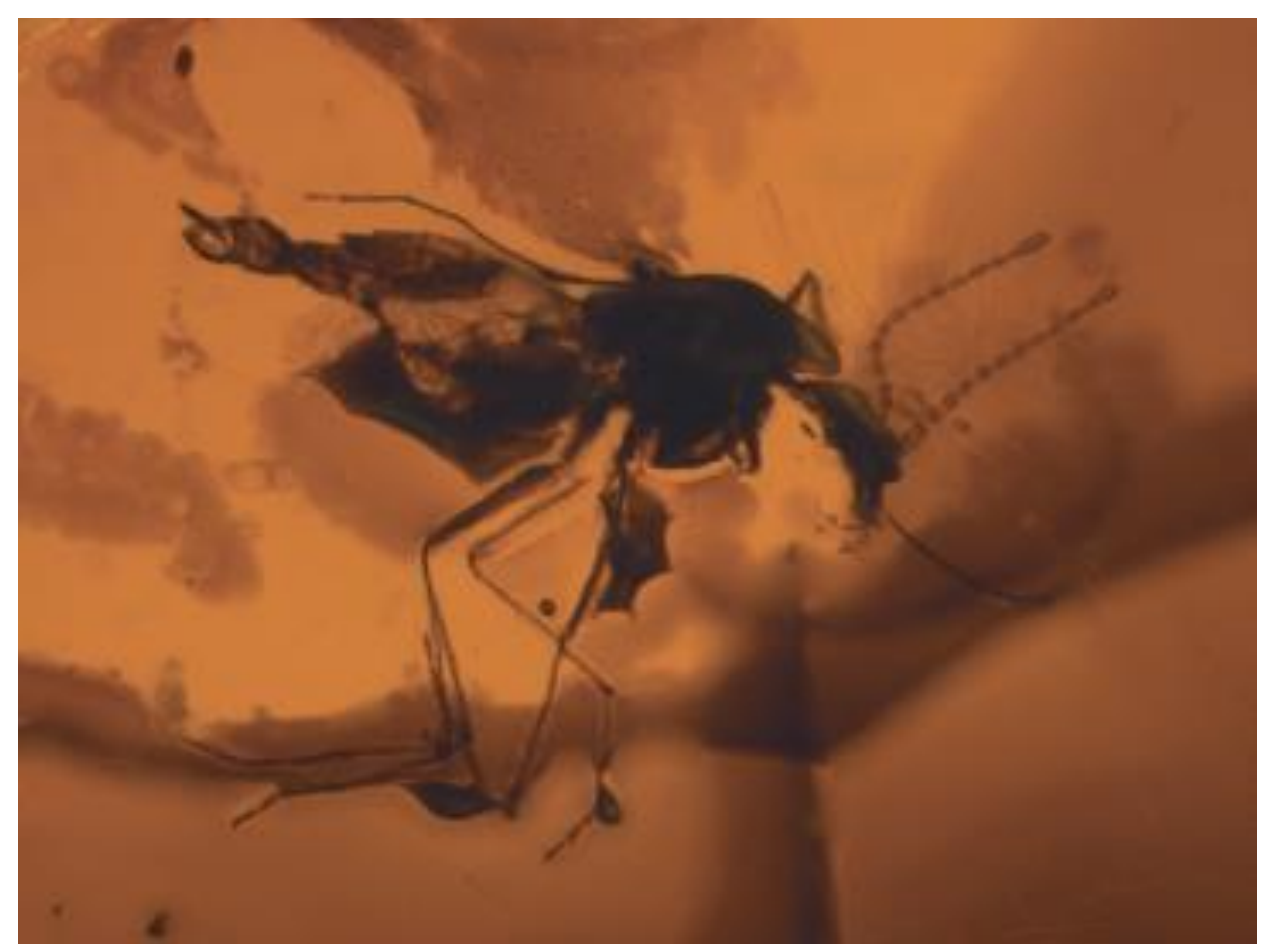

Fig. 9. Pseudosmittia kodrulae sp. n., holotype male (PIN 3387/153). 

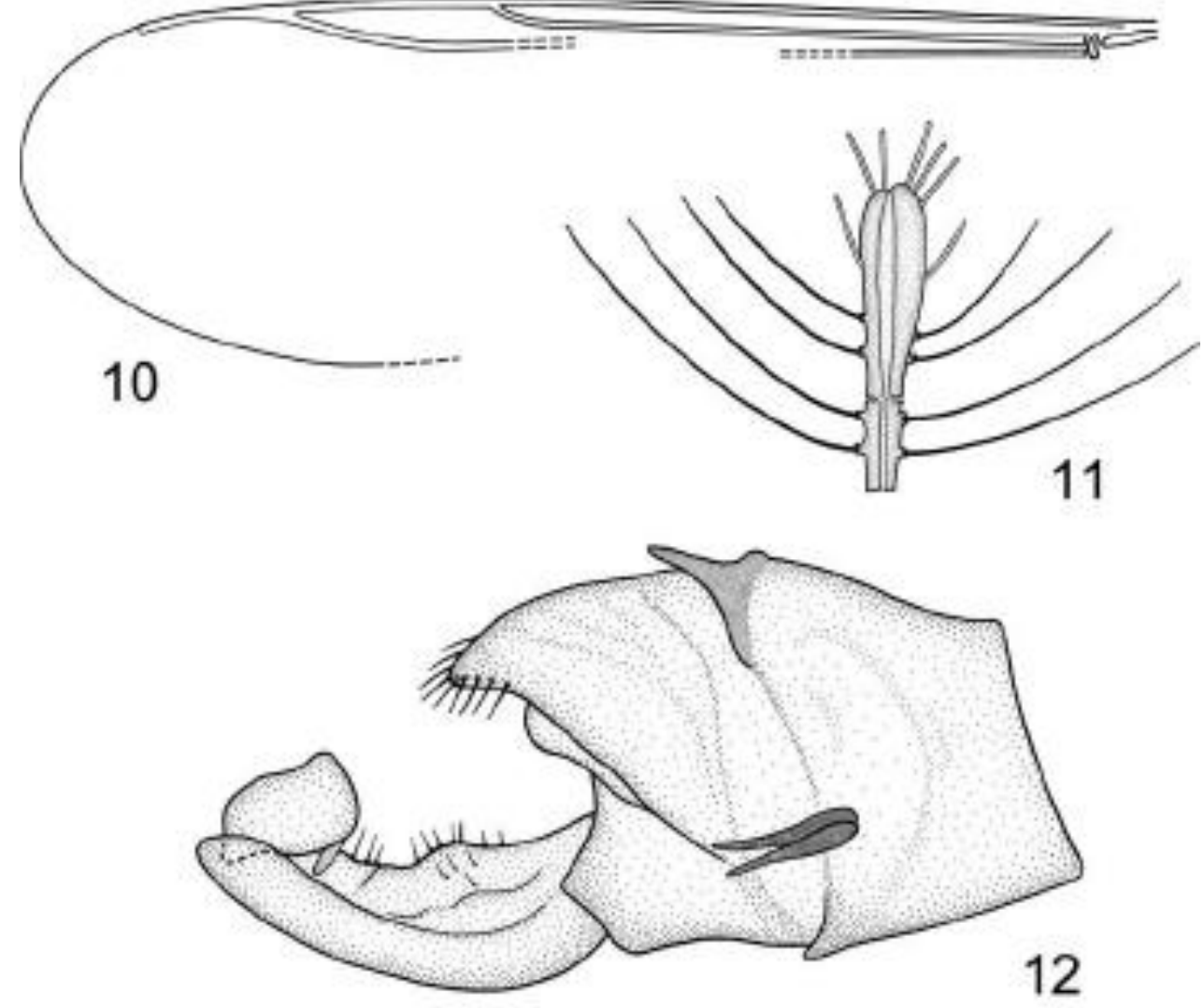

Figs 10-12. Pseudosmittia kodrulae sp. n., holotype male (PIN 3387/153), (10) wing, (11) tip of antenna, (12) hypopygium.

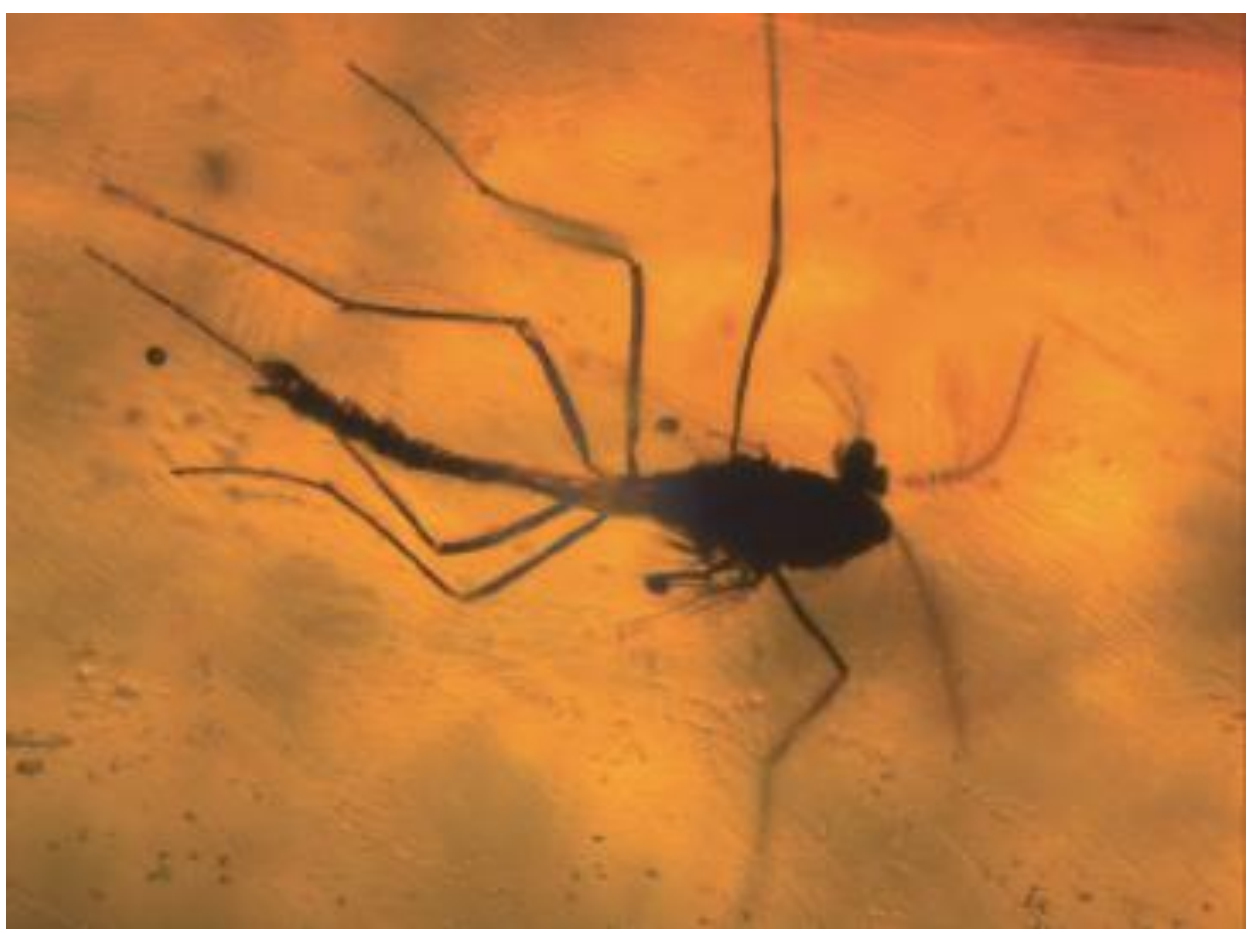

Fig. 13. Smittia sukachevae sp. n., holotype male (PIN N 3387/152). 

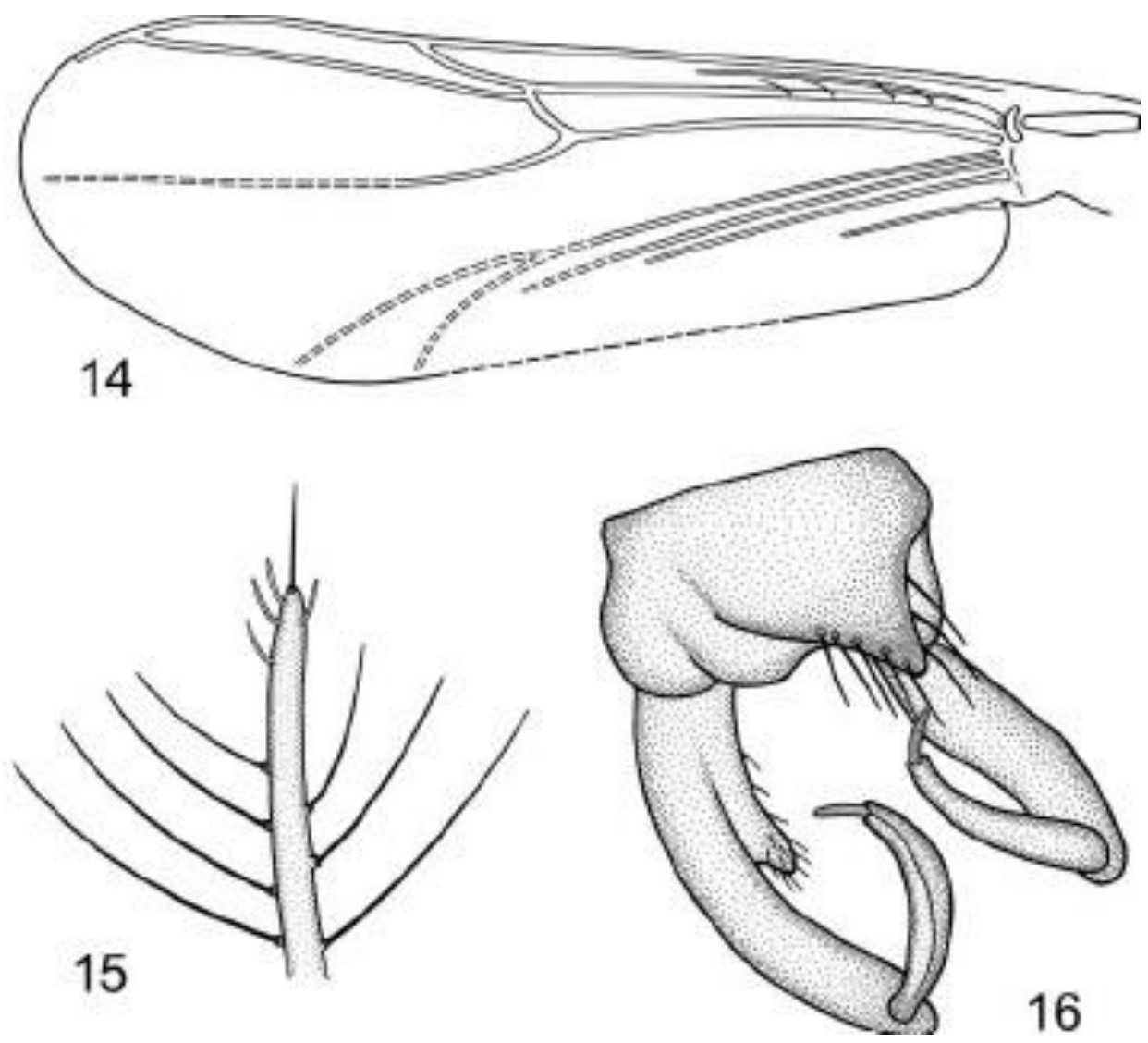

Figs 14-16. Smittia sukachevae sp. n., holotype male (PIN N 3387/152), (14) wing, (15) tip of antenna, (16) hypopygium.

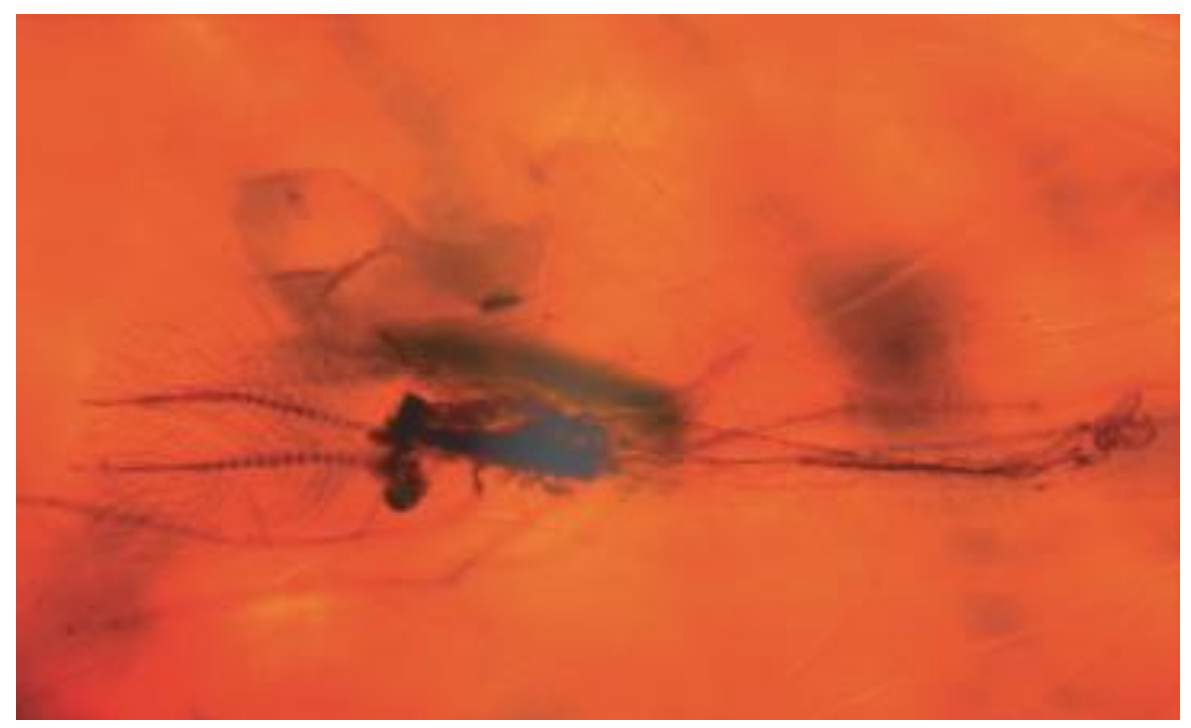

Fig. 17. Orthocladiinae sp. A., male (PIN N 3387/154). 
Table 1. Length (in $\mu \mathrm{m})$ of leg segments in Heterotrissocladius naiba sp.n., male ( $\mathrm{n}=1)$.

\begin{tabular}{llllllll}
\hline & $\mathrm{fe}$ & $\mathrm{ti}$ & $\mathrm{ta}_{1}$ & $\mathrm{ta}_{2}$ & $\mathrm{ta}_{3}$ & $\mathrm{ta}_{4}$ & $\mathrm{ta}_{5}$ \\
\hline $\mathrm{p}_{1}$ & 539 & 441 & - & - & 172 & 114 & 65 \\
$\mathrm{p}_{2}$ & 425 & 417 & - & - & - & - & - \\
$\mathrm{p}_{3}$ & - & 449 & - & - & - & - & - \\
\hline
\end{tabular}

Table 2. Length (in $\mu \mathrm{m})$ of leg segments of Paraphaenocladius nadezhdae sp. $\mathrm{n}$., male ( $\mathrm{n}=1$ - holotype).

\begin{tabular}{llllllll}
\hline & $\mathrm{fe}$ & $\mathrm{ti}$ & $\mathrm{ta}_{1}$ & $\mathrm{ta}_{2}$ & $\mathrm{ta}_{3}$ & $\mathrm{ta}_{4}$ & $\mathrm{ta}_{5}$ \\
\hline $\mathrm{p}_{1}$ & - & 678 & 400 & 229 & 173 & 123 & 74 \\
$\mathrm{p}_{2}$ & 588 & 556 & 245 & 106 & - & - & 41 \\
$\mathrm{p}_{3}$ & 620 & 694 & - & - & - & - & - \\
\hline
\end{tabular}

Table 3. Length (in $\mu \mathrm{m}$ ) of mid- and hind leg of Pseudosmittia okhotski sp. n., male $(\mathrm{n}=1)$.

\begin{tabular}{llllllll}
\hline & $\mathrm{fe}$ & $\mathrm{ti}$ & $\mathrm{ta}_{1}$ & $\mathrm{ta}_{2}$ & $\mathrm{ta}_{3}$ & $\mathrm{ta}_{4}$ & $\mathrm{ta}_{5}$ \\
\hline $\mathrm{p}_{1}$ & - & - & - & - & - & - & - \\
$\mathrm{p}_{2}$ & 192 & 236 & 92 & 40 & 36 & 24 & 24 \\
$\mathrm{p}_{3}$ & 200 & 256 & 124 & 60 & 56 & 32 & 28 \\
\hline
\end{tabular}

Table 4. Length (in $\mu \mathrm{m})$ of leg segments of Smittia dolinski sp. n., male $(\mathrm{n}=1)$.

\begin{tabular}{llllllll}
\hline & $\mathrm{fe}$ & $\mathrm{ti}$ & $\mathrm{ta}_{1}$ & $\mathrm{ta}_{2}$ & $\mathrm{ta}_{3}$ & $\mathrm{ta}_{4}$ & $\mathrm{ta}_{5}$ \\
\hline $\mathrm{p}_{1}$ & 392 & - & 261 & 172 & 123 & 78 & 49 \\
$\mathrm{p}_{2}$ & 376 & 392 & 131 & 74 & 57 & 41 & 33 \\
$\mathrm{p}_{3}$ & 392 & 351 & 229 & 147 & 106 & 41 & 33 \\
\hline
\end{tabular}

